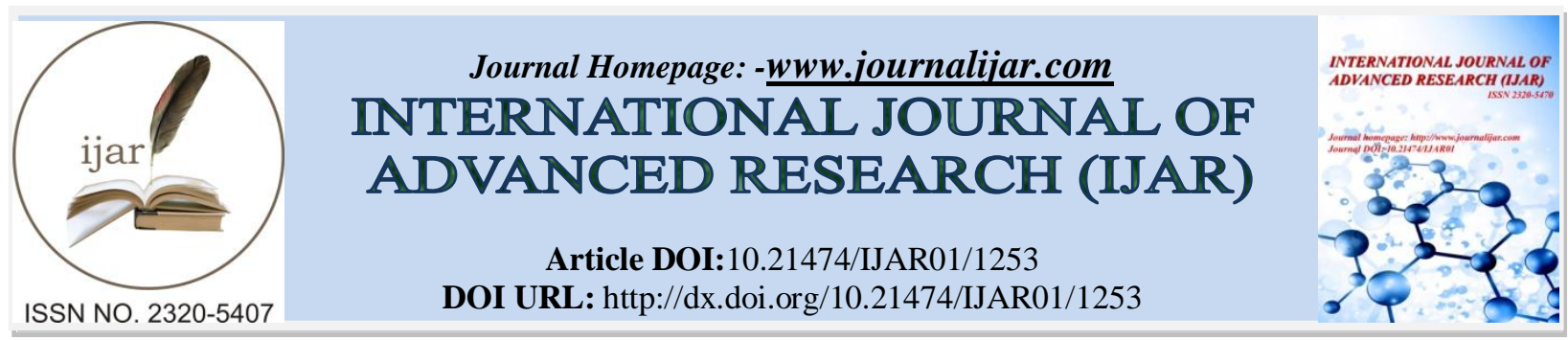

RESEARCH ARTICLE

\title{
EVALUATING THE CORPORATE COMMUNICATION STRATEGIES OF SPORTS CLUBS IN THE NEW MEDIA
}

\author{
Ali Gurel GOKSEL ${ }^{1}$ and M. Zahit SERARSLAN ${ }^{2}$ \\ 1. MuglaSitk1 KocmanUniversity, Faculty of Sport Sciences, Mugla, Turkey. \\ 2. Istanbul Gelisim University, Department of Sport Management, Istanbul, Turkey.
}

\section{Manuscript Info}

Manuscript History

Received: 19 June 2016

Final Accepted: 29 July 2016

Published: August 2016

Key words:-

Corporate Communication. New Media.

Social Media. Sport Clubs. Strategic

Management.

\begin{abstract}
The purpose of the study is evaluating the use of the new media by sports clubs as a means of corporate communication under the umbrella of public relation activities of these clubs, which are always the topic of the visual and written media every day, and which create commercial values with their income sources and supporters/customers. The universe of the study consists of all the sports clubs in Turkey. The starting point of the study consists of the report released by the website socialbakers.com, which conducts statistical analyses in the field of new media, giving the number of the followers of the sports clubs in Turkey in Facebook. In this context, the sampling of the study consists of the media accounts of the three sports clubs in Turkey, which have the most followers in the new media, Galatasaray, BeşiktaşandFenerbahçe.In examining the social network accounts, the grading method used in study with the title "Election Campaigning on the WWW in the US and the UK: A Comparative Analysis". At the end of the study it was determined that the clubs cared more for the social media. It was also determined that the clubs cared for their Facebook and Twitter accounts more, and these accounts were updated every day except for the LinkedIn andYouTubeaccounts.
\end{abstract}

Copy Right, IJAR, 2016,. All rights reserved.

\section{Introduction:-}

It is possible to claim that new technologies brought with them many opportunities to realize efficient sports marketing activities and to present the information on sports (McCoy 2010). The new developments in the technological market strengthened people and institutions; however, this situation also gave rise to an important change in the world of sports. The studies conducted so far revealed that sportsmen do not consider it sufficient to establish communication with the target audience only by traditional means of communication like newspapers (Shockley 2010).

With the Internet becoming widespread, sports clubs firstly opened their official websites; and with the ongoing innovations and developments, they were directed towards the new media. The clubs prepare their new webpages with various techniques and contents in the new media. In social networks, the sharing being the basis, presenting various applications together, and the feedback being fast are some of the characteristics of the new webpages of the sports clubs. Social networks are similar to each other in general terms; however, their contents are different. Recent 
studies show that sports clubs and various institutions use Facebook, Twitter, LinkedIn, Google+ andYouTubemostly in the social networks, which form the new media (Göksel and Serarslan 2015).

Corporate communication is a give-and-take cycle which is realized through mutual symbols, signs, actions and relations between the ideas, which provide opportunities for constant information flow and mutual thoughts either around the organization or within the organization between the sub-departments or groups, which constitute the corporate structure in order to continue its existence (Canpolat et al. 2013). It may also be defined as the communication and relation management process which covers the fields that are intended to convert the organization into such a structure that is appreciated by the society with an increased performance (Huang and Kleiner 2005; Kucuk 2005; Ozdemirci 2006; Kadibesegil 2009).In other words, corporate communication is the one established with the customers, suppliers and all the other internal and external stakeholders of an organization. Corporate communication meansundertaking an important role in creating a corporate image (Johan and Noor 2013; Özel 2014).

Strategic corporate communication is providing the details of the steps of the corporate communication works in an integrated structure, and also providing feedback for the possible problems that may appear during the processes (Peltekoglu 2001).It is not possible that the strategically management applications, which are not considered and planned as a continuous process, will achieve success (Ulgen and Mirze 2013).

When the new media concept is examined in the literature, it is observed that the general understanding is in the direction of communication technologies and their practices (Tami et al. 2010). The new mediaconcept expresses the websites and other digital communication and information channels, which have the properties of being received/consumed by others -no matter what the localizations of the active users are (Thorsten et al. 2010). According to Tami et al. (2010), the new media concept expresses the emergence of the communication technologies and their applications. In this study, which is planned to be conducted, the new media concept is handled as the Internet and digital technology applications (websites, social media, social networks, file sharing programs, etc.).

Today, sports clubs develop a network of relations, which cover the internal and external elements as a basic requirement of their corporate management, and thus face the structure, which is called as the corporate communication in the management of their established relations (Yetim and Cengiz 2012). Organizational communication is observed as the establishment of communication in the direction of the purposes with all the available elements in the organization. Generally, organizational communication covers the areas of public relations, corporate communication, advertisements, communicationwith the employees, communication with the supporters, and communication with the media processes for a sports institutions.It is considered that speeding this process up is only possible by not staying behind the contemporary developments and benefiting more from the virtual world (Göksel and Serarslan 2015).

\section{Material and method:-}

\section{The Purpose and the Importance of the Study:-}

The purpose of the study is evaluating the use of the new media by sports clubs as a means of corporate communication under the umbrella of public relation activities of these clubs, which are always the topic of the visual and written media every day, and which create commercial values with their income sources and supporters/customers. Our study is important in that it will reveal the evaluation of the social media, which is both an opportunity for sports clubs and a risk factor, and which is used actively more and more day by day in managerial field, and it will contribute to the literature in this field since there are few studies on this topic.

\section{The Method of the Study:-}

The method of the study is the Content Analysis Method, which is one of the Quantitative Research Methods. Content Analysis is the one which is conducted to measure the variables in a text in a systematic, unbiased and digital manner. In other words, content analysis means converting a verbal or written text into numbers by analyzing and making evaluations based on these numbers,i.e. converting the numbers into words.

\section{The Universe and the Sampling of the Study:-}

The universe of the study consist of all the sports clubs in Turkey. The starting point of the study consists of the report released by the website socialbakers.com, which conducts statistical analyses in the field of new media, and which is frequently referred to in scientific studies. Their report gives the number of the followers of the sports clubs 
in Turkey on Facebook. The data in this website are prepared as based on the interest of the followers in the brands or institutions. In this context, there are three sports clubs in the first ten place in Facebook followers report. In this context, the sampling of the study consists of the corporate media accounts of the three sports clubs in Turkey, which have the most followers and supporters in the new media, Galatasaray Sports Club, Fenerbahçe Sports Club and Beşiktaş Gymnastics Club.

\section{The Problem of the Study:-}

The problem of the study is determining the strategic corporate communication activities, and the management of these activities, which are applied in official social media accounts of these clubs in the new media, which is the new means of corporate communication by the sports clubs, especially the public relations departments or the corporate communication practitioners of these clubs.

\section{Data Collection Tool:-}

In examining the social networks, the grading system, which was used by Gibsonet al. (2003) in their study "Election Campaigning on the WWW in the US and the UK: A Comparative Analysis",was used as the basis. The study consists of two parts, the first part has the title Functions with the subtitles; The Method,Information Flow, Collecting the Sources, Communication Network, Participation, and the Campaign; and the second part has the title Presentation with the subtitles; Visuality, Accessibility, Strolling, Actuality, and Visibility. By considering the specific technical structure and the contents of the social networks,small changes were made in the index and grading system, which was used by Gibson et al. In terms of the efficiency of the study, the data obtained via the abovementioned social networks were graded, and the other communication messages which were spread via other means of communication were not considered.

\section{Collection of the Study Data:-}

The data collection was performed by the researcher himself. The social media networks of the three sports clubs, which were included in the study, i.e. the Facebook, Twitter, LinkedIn, Google+ andYouTubeaccounts were examined by the researcher for 3 months and the necessary data were collected.

\section{The Limitations of the Study:-}

The limitations of the study are being conducted with three sports clubs and the social network accounts of these sports clubs,Facebook, Twitter, LinkedIn, Google+ andYouTube; and the study date being between October and December.

\section{The Assumption of the Study:-}

It has been assumed that the sports clubs, which constitute the sampling of the study, represent the universe of the study. In addition, it has also been assumed that the data collection tool used in the study is the best and accurate data collection tool in achieving the purpose of the study and the desired results.

\section{Findings:-}

When Table-1is examined carefully it is observed that the Galatasaray, Fenerbahçe and Beşiktaş sports clubs have Facebook, Twitter, YouTubeand Google+ pages. On the other hand, only Galatasaray and Fenerbahçe sports clubs have LinkedIn; and Beşiktaş does not have an official LinkedIn account. The new means of media -except for the Instagram- of the sports clubs, Galatasaray, Fenerbahçe and Beşiktaş, were evaluated in terms of function and presentation, and the results are given in the further parts of the study. Since Instagram allows only the sharing of photographs, it was not analyzed thinking that it would not lead to any extra awareness.

Table1:-The New Means of Media of the Sports Clubs.

\begin{tabular}{|c|c|c|c|}
\hline Social Networks / Sports Clubs & Galatasaray & Fenerbahçe & Beşiktaş \\
\hline Facebook & + & + & + \\
\hline Twitter & + & + & + \\
\hline LinkedIn & + & + & - \\
\hline Google+ & + & + & + \\
\hline YouTube & + & + & + \\
\hline
\end{tabular}

When Table 2, which shows the Functions, is examined, it is observed that GS represents Galatasaray, FB represents Fenerbahçe and BJK represents Beşiktaş sports clubs. It is observed in the Information Flow sub-title in the table 
that the highest points of the clubs are collected from the Facebook accounts. Again,the "Who is Who", and the "Investment Info of the Club" sub-titles are not included in any social media account of the three sports clubs. In the Collecting the Resources sub-title, it is observed that there is Membership Index in all social media accounts of the clubs except for the Google+ andYouTubeaccounts. The links on the communicationnetwork vary between 0-5 points. It was determined that the most points were obtained in the Twitter accounts by the clubs from the external communication links in which the national and international partners were included, and from the internal communication links in which the other institutions were included. In the sub-title where the conveyance method of the campaigns are examined, it is interesting that the three clubs received full points in the Facebook and Twitter accounts.

Table2:- The Functional Characteristics of the Social Media Accounts of the Sports Clubs.

\begin{tabular}{|c|c|c|c|c|c|c|c|c|c|c|c|c|c|c|c|}
\hline \multirow[b]{2}{*}{ FUNCTIONS PART } & \multicolumn{3}{|c|}{ FACEBOOK } & \multicolumn{3}{|c|}{ TWITTER } & \multicolumn{3}{|c|}{ LINKEDIN } & \multicolumn{3}{|c|}{ GOOGLE+ } & \multicolumn{3}{|c|}{ YOUTUBE } \\
\hline & $\mathbb{B}$ & 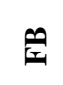 & $\mathscr{v}$ & $\mathscr{U}$ & $\stackrel{\varphi}{\Phi}$ & $\ddot{\theta}$ & $\mathscr{U}$ & $\stackrel{\infty}{a}$ & $\mathscr{\theta}$ & 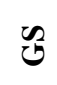 & 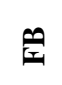 & $\mathscr{\theta}$ & $\mathcal{B}$ & $\stackrel{\infty}{a}$ & $\stackrel{\Delta}{0}$ \\
\hline \multicolumn{16}{|l|}{ Information Flow } \\
\hline $\begin{array}{l}\text { Conveying the Corporate } \\
\text { Visual Identity }\end{array}$ & + & + & + & + & + & + & + & - & & + & + & + & + & + & + \\
\hline Corporate History & + & + & + & - & - & + & + & - & & - & - & + & - & - & - \\
\hline $\begin{array}{l}\text { Corporate Philosophy / } \\
\text { Mission/Vision }\end{array}$ & + & - & - & - & - & - & - & - & & - & - & - & - & - & + \\
\hline Corporate Slogan Used & + & - & - & + & + & - & - & - & & - & - & - & - & - & + \\
\hline Who is Who in the Club & - & - & - & - & - & - & - & - & & - & - & - & - & - & - \\
\hline $\begin{array}{l}\text { Leader of the Club and his/her } \\
\text { Message }\end{array}$ & - & - & - & - & - & - & - & - & & - & - & + & - & - & + \\
\hline Product/Service Info & + & + & + & + & + & + & - & - & & + & - & + & + & + & + \\
\hline Investment Info of the Club & - & - & - & - & - & - & - & - & & - & - & - & - & - & - \\
\hline Advertisements of the Club & + & + & + & + & + & + & - & - & & + & - & + & + & + & + \\
\hline $\begin{array}{l}\text { Relations with the Media / } \\
\text { Press Room }\end{array}$ & + & + & + & + & + & + & - & - & & + & + & + & + & + & + \\
\hline Activities / Notifications & + & + & + & + & + & + & - & - & & + & + & + & + & - & + \\
\hline Ticket Price Info & + & + & - & + & + & + & - & - & & - & - & + & - & - & - \\
\hline Contact Info & + & + & + & - & - & - & + & + & & + & - & + & - & - & - \\
\hline $\mathbf{0 / 1 3}$ & 10 & 8 & 7 & 7 & 7 & 7 & 3 & 1 & & 6 & 3 & 9 & 5 & 4 & 8 \\
\hline \multicolumn{16}{|l|}{ Collecting Resources } \\
\hline Help Index & - & - & - & - & - & - & - & - & & - & - & - & - & - & - \\
\hline Archives İndex & - & - & - & - & - & - & - & - & & - & + & + & + & + & + \\
\hline Membership İndex & + & + & + & + & + & + & + & + & & + & + & + & + & + & + \\
\hline Volunteering İndex & - & - & - & - & - & - & - & - & & - & - & - & - & - & - \\
\hline $0 / 4$ & $\mathbf{1}$ & 1 & 1 & $\mathbf{1}$ & 1 & 1 & $\mathbf{1}$ & 1 & & 1 & 2 & 2 & 2 & 2 & 2 \\
\hline \multicolumn{16}{|l|}{ Communication Network } \\
\hline Internal Communication & 14 & 7 & 5 & 21 & 17 & 16 & 1 & 1 & & 11 & 8 & 4 & 5 & 8 & 8 \\
\hline External Communication & 5 & 3 & 5 & 52 & 52 & 42 & 0 & 0 & & 1 & 0 & 7 & 0 & 0 & 1 \\
\hline $0 / 5$ & $2 / 1$ & $1 / 1$ & $1 / 1$ & $3 / 4$ & $2 / 4$ & $2 / 3$ & $1 / 0$ & $1 / 0$ & & $2 / 1$ & $1 / 0$ & $1 / 1$ & $1 / 0$ & $1 / 0$ & $1 / 1$ \\
\hline \multicolumn{16}{|l|}{ Participation } \\
\hline E-Mail & + & + & + & - & - & - & - & - & & + & - & + & - & - & - \\
\hline Visitors' Book & + & + & + & + & + & + & - & - & & + & + & + & - & + & - \\
\hline E-Magazine & + & - & - & - & - & - & - & - & & - & - & - & - & - & - \\
\hline $\mathbf{0} / \mathbf{3}$ & 3 & 2 & 2 & 1 & 1 & 1 & $\mathbf{0}$ & $\mathbf{0}$ & & 2 & 1 & 2 & $\mathbf{0}$ & 1 & $\mathbf{0}$ \\
\hline \multicolumn{16}{|l|}{ Campaigns } \\
\hline $\begin{array}{l}\text { Negative Campaigns being } \\
\text { Non-existent }\end{array}$ & + & + & + & + & + & + & + & + & & + & + & + & + & + & + \\
\hline $\begin{array}{l}\text { Conveying Social } \\
\text { Responsibility Campaigns }\end{array}$ & + & + & + & + & + & + & - & - & & + & - & + & + & - & + \\
\hline $\begin{array}{l}\text { Conveying Product/Service } \\
\text { Campaigns }\end{array}$ & + & + & + & + & + & + & - & - & & + & - & + & + & + & + \\
\hline $\begin{array}{l}\text { Download (Logo / Screensaver } \\
\text { etc.) }\end{array}$ & + & + & + & + & + & + & - & - & & + & + & + & - & - & - \\
\hline $0 / 4$ & 4 & 4 & 4 & 4 & 4 & 4 & 1 & 1 & & 4 & 2 & 4 & 3 & 2 & 3 \\
\hline
\end{tabular}


When we consider Table 3, which shows the detailed data on the Presentation Part, it is observed that the sports clubs share "Animated Images", "Pictures" and "Videos" provided that they are allowed by the social media under the Visuality sub-title. It is also observed that they do not have any contents in LinkedInaccounts. When the accounts are examined in terms of being updated, it is observed that the clubs share the most up-to-date information in Facebook and Twitter accounts; and Galatasaray and Fenerbahçe Sports clubs do not share any up-to-date data in their LinkedIn accounts. In addition, it is also observed that Fenerbahçe uploads new content in the YouTube account once in every two weeks.

Table3:-Presentation Characteristics of the Social Media Accounts of the Sports Clubs.

\begin{tabular}{|c|c|c|c|c|c|c|c|c|c|c|c|c|c|c|c|}
\hline \multirow[b]{2}{*}{ PRESENTATION PART } & \multicolumn{3}{|c|}{ FACEBOOK } & \multicolumn{3}{|c|}{ TWITTER } & \multicolumn{3}{|c|}{ LINKEDIN } & \multicolumn{3}{|c|}{ GOOGLE+ } & \multicolumn{3}{|c|}{ YOUTUBE } \\
\hline & $\mathcal{G}$ & $\stackrel{\theta}{I}$ & $\mathscr{a}$ & $\mathcal{B}$ & $\stackrel{\theta}{a}$ & $\mathscr{a}$ & $\mathcal{E}$ & $\underline{|c|}$ & 幽 & $\mathcal{E}$ & $\stackrel{\theta}{|c|}$ & $\mathscr{a}$ & తి & 斑 & $\stackrel{v}{a}$ \\
\hline \multicolumn{16}{|l|}{ Visuality } \\
\hline Graphics & - & - & - & - & - & - & - & - & & - & - & - & - & - & - \\
\hline Frames & - & - & - & - & - & - & - & - & & - & - & - & - & - & - \\
\hline Mobility/İmages & + & + & + & + & + & + & - & - & & + & + & + & - & - & - \\
\hline Sound & + & + & + & + & + & + & - & - & & + & + & + & + & + & 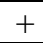 \\
\hline Video & + & + & + & + & + & + & - & - & & + & + & + & + & + & 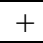 \\
\hline Animation & - & - & - & - & - & - & - & - & & - & - & - & - & - & - \\
\hline $0 / 6$ & $\mathbf{3}$ & 3 & $\mathbf{3}$ & 3 & $\mathbf{3}$ & $\mathbf{3}$ & $\mathbf{0}$ & $\mathbf{0}$ & & 3 & 3 & 3 & 2 & 2 & 2 \\
\hline \multicolumn{16}{|l|}{ Accessibility } \\
\hline $\begin{array}{l}\text { All Website being Presented as } \\
\text { Text }\end{array}$ & + & + & + & + & + & + & + & + & & + & + & + & - & - & - \\
\hline $\begin{array}{l}\text { Downloading the Documents as } \\
\text { Text }\end{array}$ & + & + & + & + & + & + & - & - & & + & + & + & - & - & - \\
\hline Wireless Access via WAP/PDA & + & + & + & + & + & + & + & + & & + & + & + & + & + & + \\
\hline $\begin{array}{l}\text { Software for the Visually } \\
\text { İmpaired People }\end{array}$ & - & - & - & - & - & - & - & - & & - & - & - & - & - & - \\
\hline $0 / 4$ & 3 & 3 & $\mathbf{3}$ & 3 & 3 & 3 & 2 & 2 & & 3 & 3 & 3 & 1 & 1 & 1 \\
\hline \multicolumn{16}{|l|}{ Strolling } \\
\hline Strolling Clues & + & + & + & + & + & + & - & - & & + & + & + & + & + & + \\
\hline Number of the Search Engine & - & - & - & - & - & - & - & - & & + & + & + & + & + & + \\
\hline $\begin{array}{l}\text { The Main Page Icon being Below } \\
\text { the Page }\end{array}$ & - & - & - & - & - & - & - & - & & - & - & - & + & + & + \\
\hline $\begin{array}{l}\text { The Fixed Menu Bars being } \\
\text { Below the Page }\end{array}$ & - & - & - & - & - & - & - & - & & - & - & - & + & + & + \\
\hline Site Map & - & - & - & - & - & - & - & - & & - & - & - & - & - & - \\
\hline $0 / 5$ & $\mathbf{1}$ & 1 & 1 & $\mathbf{1}$ & 1 & 1 & $\mathbf{0}$ & $\mathbf{0}$ & & 2 & 2 & 2 & 4 & 4 & 4 \\
\hline \multicolumn{16}{|l|}{ Update } \\
\hline Everyday & + & + & + & + & + & + & - & - & & + & - & + & - & - & - \\
\hline Once in 1-2 Days & - & - & - & - & - & - & - & - & & - & + & - & - & - & + \\
\hline Once in 3-7 Days & - & - & - & - & - & - & - & - & & - & - & - & + & - & - \\
\hline Once in Two Weeks & - & - & - & - & - & - & - & - & & - & - & - & - & + & - \\
\hline Once a Month & - & - & - & - & - & - & - & - & & - & - & - & - & - & - \\
\hline Once in 1-6 Months & - & - & - & - & - & - & - & - & & - & - & - & - & - & - \\
\hline More than 6 Months & - & - & - & - & - & - & + & + & & - & - & - & - & - & - \\
\hline $0 / 6$ & 6 & 6 & 6 & 6 & 6 & 6 & 0 & 0 & & 6 & 5 & 6 & 4 & 3 & 5 \\
\hline
\end{tabular}

\section{Discussion:-}

The sports clubs included in the study are interested more in Facebook, Twitter, LinkedIn, Google+ andYouTube, since their contents are not complex, it is easy to create an account without too much effort and it is free of charge. LinkedIn,which is a means of social media, show differences in terms of its function when compared with the other social media accounts. Again, videos about the clubs are shared with the members by creating an account in YouTube. The mostdistinctivedifference of the YouTube account is that the sports clubs do not consider it as an 
interactive means of communication. All of the clubs except one of them do not prepare the contents to allow the members write comments.

It is also another interesting point that football is considered as having the most important role in the development of the media services in our country, which is the case in many other countries in the world. Here, the justification of this is presented as the means of information and communication technologies being prepared and presented according to a certain demographic structure or according to fanatic groups. Men, who are in their mid-twenties or thirties, constitute the highest customer group in football and in the new media technologies, and the target market that has emerged as a result of these new technologies, is important for the sports media industry. In this context, it is important that the new media products and services from the digital TV broadcasting to $3 \mathrm{G}$ mobile phones must be prepared according to the benefits of this target group. This situation is obvious in the advertisement and sponsorship of some brands like NTL, Telewest, BSkyB, Granada Media,BT, Vodafone, Orenge, O2, T-Mobile, Nokia and Siemens spend the majority of their financial assets to gain the British football supporters (Beech and Chadwick 2007).

When conducted a study in which the relation between football and the new media was examined and reported that there were struggles to establish a connection between the football fans and the new communication technologies. In this context, it was also observed that the demands of the supporters were covered by the football industry (Çavuşoğluet al.2011). Sports clubs have to conductexplorations and make decisions before they show up in the means of new media, and define their new media strategies. The clubs which do not have any new media strategies may face great problems in accompanying the new media dynamics. In general terms, the new media strategy defines the targets, aims, identity, the language and the style in the webpage, the properties of the target audience, the characteristics of the internal and external resources, and the scope of the reports of the club for the accounts in the new media. The new media strategies are very important for sports clubs since there are always institutions, people or groups that may be influenced by these strategies either in a positive or in a negative manner.

Figure1:- Institutions and People who are Directly Related with the New Media in Sports Clubs.

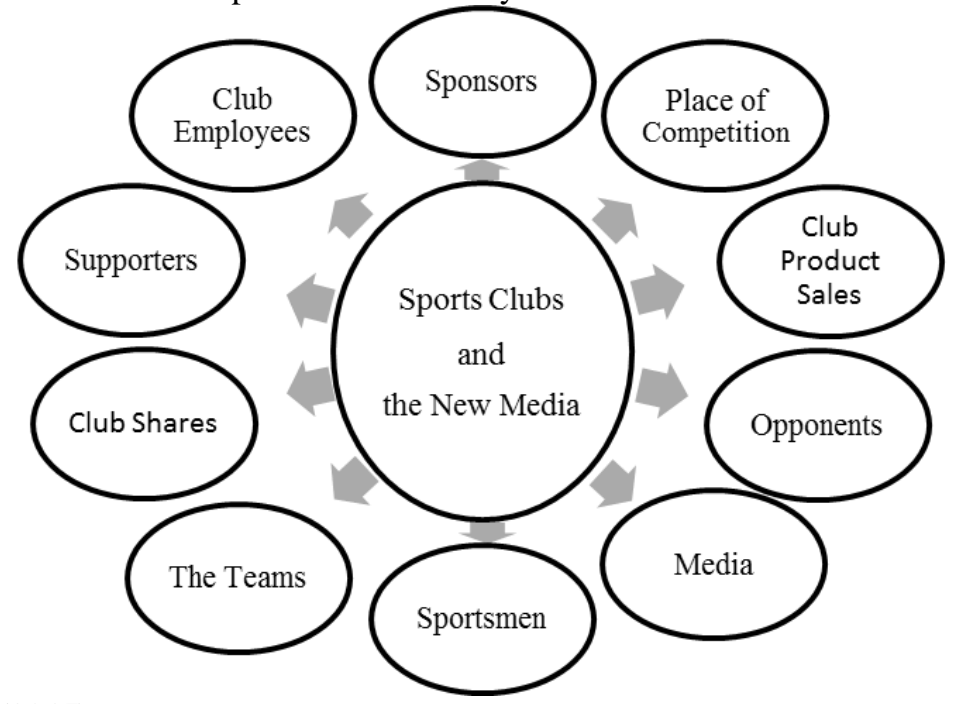

Göksel and Serarslan (2015):-

One of the most importantmanagerial activities is, without doubt, the feedback showing the results of the work that has been done so far. In the grading of the new media accounts, the tactics such as being open and clear to the virtual world, active usage rate in order to ensure participation, the distribution of the sharing being spread like in the viral marketing. All that aside, it is known that the number of the followers of the sports clubs in official social media accounts, and the duration spent on these pages, likes, sharing, comments and other interaction activities are also important. In addition, social marketing is important in forming a sports culture for the sports clubs. Kargün et al. (2015) conducted a study and reported that social marketing had a specific importance in increasing the sports conscience. It was reported that the NBA teams had interactiveand informative sharing on their accounts in order to make use of the new media platforms (Wysocki 2012). 
Kietzmann et al.(2011) conducted a study and determined that most NBA teams had various accounts in social media and these accounts were managed from one single center. It was also reported that the most-preferred new media tools were Twitter, Facebook, YouTube, Google+, Instagram, Pinterest, Tumblr and LinkedIn. In this context, when we consider the popularity of the social media accounts in Turkey, which is the main subject of our study, it is possible to claim that our findings overlap with the results reported by Kietzmann et al. and that we have reached our goals in this study.

\section{Conclusion:-}

It has been determined with the research on the new media tools that Galatasaray, Fenerbahçe and Beşiktaş sports clubs have official Facebook, Twitter, Google+ andYouTubeaccounts. It has also been determined that except for Beşiktaş Sports Club, the other clubs have official LinkedIn pages. In the research, the following results have been reached in the detailed analyses of the new media accounts:

* It has been determined that the number of the followers of the sports clubs, which are included in the scope of the study, increased with each passing day.

* Sports clubs are in constant communication with their supporters via the new media tools.

* The supporters/customers and the sports clubs mostly prefer Facebook in the new media, and Twitter is in the second row after Facebook.

* It has also been observed that the sports clubs and their followers are not interested much in LinkedIn. Beşiktaş sports club does not even have a LinkedIn account.

* It has been determined that Beşiktaş sports club uses Google+ account in the most active manner. Galatasaray and then Fenerbahçe follow Beşiktaş in this context.

* It has been determined that the sports clubs care much for conveying the visual identity in their official new media accounts.

* It has been observed that the most informative account on the corporate history is Beşiktaş sports club in social media accounts.

* The corporate philosophy, missions, and the visions of the three sports clubs, which were included in the study, are not given in a sufficient manner for the followers in their accounts.

* The managers or the professional employees of the sports clubs are not mentioned clearly.

* It has also been determined that, except for the compulsory notifications made to the Enlightening the Public Platform, sports clubs do not share their investment profiles in social networks.

* The ticket prices of the clubs in various sports branches are not available on social media accounts except for Facebook and Twitter.Only Beşiktaş sports club mentions this information on its Google+ account.

* Sports clubs mention the contact information and provide the links to their other new media links on their Facebook, LinkedIn and Google+ accounts.

* The e-mail addresses are not shared except for Facebook and Google+ instead, the official websites ofthe clubsarementioned in all networks.

* It has been determined that only Galatasaray sports club has an e-magazine on its official Facebook account.

* The clubs included in the study upload videos on their new media tools and these videos are easily watched by their followers.

* The accounts of the clubs on social media areupdated every day except for LinkedIn andYouTubeaccounts.

\section{Recommendations:-}

In the light of the conclusions obtained in the study, the recommendations to the sports clubs, to the corporate communicationexecutives and to the scientists, who are planning new studies, are as follows:

* The targets, corporate philosophy, mission, vision and considerations of the sports clubs, which must be known by the followers, must be given more place on the new media accounts.

* It has been determined that the main slogan, which provides information on the corporate identity and which shows the targets of these ports club at that time by reflecting the corporate culture, are not given sufficient place on the majority of the social networks.

* In the evaluation made in terms of the communicationnetwork functions, it has been observed that sports clubs share the required contact information on social networks. However, there is no information on the subbranches, which exist in the club in managerial terms (marketing, accountancy, etc.), and this prevents reaching the right person at the right time in a quick manner.

* When the new media accounts are evaluated in terms of accessibility it has been observed that one of the most important issues is the contents being provided in foreign language. It is considered that especially the sports 
clubs that compete in international area in different sports branches must have new media accounts in various foreign languages, mainly English;and determine the countries in which they have the most followers. By doing so, they will not fall back from the far-eastern market.

* The researchers who are planning to conduct studies on public relations in sports and social media as a means of corporate communicationmust also include small-scale sports clubs to reveal the differences.

\section{References:-}

1. Beech J, Chadwick S. 2007. The marketing of sport. UK Prentice Hall.

2. Canpolat N, Kisac A, Byashimov G. 2013. Kurumsal iletisimde iki stratejik alan: pazarlama ve halkla iliskiler uzerine bir degerlendirme, Nigde Universitesi IIBF Dergisi, 6(2): 259-274.

3. Cavusoglu B, Ozturk RG, Kara B. 2011. Spor pazarlama çalismalarinda yeni medya araci olarak internet kullaniminin stratejik onemi: Turkiye ve Ingiltere'deki spor kuluplerinin web sayfalarinin incelenmesi. International Journal of Human Sciences, 8(1): 1342-1363.

4. Geray H. 2003. İletisim ve Teknoloji Uluslararasi Birikim Duzeninde Yeni Medya Politikalari. Ankara: Utopya Yayinevi.

5. Gibson RK, Margolis M, Resnick D, Ward SJ. 2003. Election campaigning on the www in the US and the UK: a comparative analysis. Party Politics, 9(1): 47-75.

6. Göksel AG, Serarslan MZ. 2015. Public relations in sports clubs: New media as a Srategic Corporate Communication Instrument. International Journal of Physical Education, Sports and Health, 2(2): 275-283.

7. Huang N, Kleiner BH. 2005. New developments concerning corporate communications. Management Research News, 28(10): 57-64.

8. Johan MRM, Noor AZM. 2013. The role of corporate communication in building organization's corporate reputation: an exploratory analysis, Interdisciplinary Journal of Comtemporary Research in Business,4(12): 1230-1240.

9. Kadibesegil S. 2009. Simdi stratejik iletisim zamani. Istanbul Mediacat Kitaplari.

10. Kargün M, Dalkilic M, Alpullu A, Pala A. 2015. The effect of social marketing on increasing sport consciousness. International Journal of Science Culture and Sport, 3(3): 18-24.

11. Kietzmann JH, Hermkens K, McCarthy IP, Silvestre BS. 2011. Social media? Get serious! Understanding the functional building blocks of social media. Business Horizons, 54: 241-251.

12. Kucuk F. 2005. Kurum imajı acisindan kurumsal iletisim. Doğu Anadolu Bölgesi Araştırmaları, 45-52.

13. McCoy MI. 2010. Sports information in digital age: a case study of lehigh athletics. Degree of Bachelor Arts. Lehigh University,USA.

14. Özdemirci F. 2006. Kurumsal iletisim ve belge yonetimi. I. Uluslararasi Bilgi Hizmetleri Sempozyumu'nda Sunulan Bildiri, İstanbul.

15. Özel EK. 2014. Calisanların Twitter kullaniminin, kurum imajına etkisi: Turkiye'de bir anket çalısmasi. Journal of Yasar University,9(35): 6138-6158.

16. Peltekoğlu FB. 2001. Halkla iliskiler nedir?Istanbul: Beta Yayinlari

17. Shockley J. 2010. Unfiltered? A Content Analysis of Pro Atheletes "Twitter" Use. Master of Arts in Professional Communication. East Tennessee State University, USA.

18. Tami KT, Youngwon L, April PB. 2010. New media research publication trends and outlets in communication, 1990-2006. New Media \& Society, 12(4):532.

19. Thorsten HT, Edward C. Malthouse CF, Sonja G, Lara Lt, Arvind R, Bernd S. 2010. The impact of new media on customer relationships. Journal of Service Research, 13(3): 312.

20. Ulgen H, Mirze K. 2013. Isletmelerde Stratejik Yonetim. İstanbul: Beta.

21. Wysocki M. 2012. The Role of Social Media in Sports Communication: An Analysis of NBA Teams' Strategy. The Faculty of The Public Communication Graduate Program, School of Communication American University, Washington DC.

22. Yetim AA, Cengiz R. 2012. Iletisim ve spor. Ankara: Berikan Yayinevi. 